\title{
Effect of Planting Density on the Yield and Growth of Intercropped Tomatoes and Peppers in Florida
}

\author{
Ravneet K. Sandhu and Nathan S. Boyd \\ Gulf Coast Research and Education Center, University of Florida, Balm, FL \\ 33598
}

\section{Lincoln Zotarelli \\ Department of Horticultural Sciences, University of Florida, Gainesville, FL 32611}

\section{Shinsuke Agehara and Natalia Peres \\ Gulf Coast Research and Education Center, University of Florida, Balm, FL 33598}

Additional index words. vegetable production, competition, density dependent, LER, photosynthesis

\begin{abstract}
Florida vegetable growers are facing high production costs due to high input costs, lower profitability, and competition from foreign markets. Multi/intercropping allows growers to increase the yields and profits per unit area by producing multiple crops on the same beds. Experiments determining the effects of intercropping and plant spacing was conducted in Fall 2018 and 2019 at Gulf Coast Research and Education Center, Balm. Tomato and bell pepper were intercropped at low and high planting density on plastic-covered beds. Bell pepper shoot biomass was significantly $(P<0.001)$ reduced when intercropped with tomato, compared with monocropped bell pepper. However, tomato shoot biomass was significantly reduced when tomato plant density increased, but it was unaffected by bell pepper intercropping. Biomass of both crops was unaffected by relay cropping. Bell pepper yields when intercropped with tomato at low density $(60 \mathrm{~cm}$ tomato-tomato and $38 \mathrm{~cm}$ pepper-pepper) had similar yields to bell pepper planted alone in low and high planting density. We concluded that bell pepper plants were more sensitive to interspecific competition, whereas tomato plants were more sensitive to intraspecific competition. Intercropping may be a viable option for growers at recommended plant densities used for monocrops. However, high plant density is not recommended.
\end{abstract}

Tomato (Solanum lycopersicum L.) and bell pepper (Capsicum annuum L.) are important vegetable crops that belong to the Solanaceae family. Florida is the leading state in fresh market tomato production and the second-leading state in bell pepper production, with an average production of 0.4 and 0.2 million metric tons, respectively (USDA-NASS, 2016). In the United States, the total tomato production has decreased from 0.7 million metric tons in the year 2000

Received for publication 5 Nov. 2020. Accepted for publication 15 Dec. 2020.

Published online 15 January 2021.

We would like to thank the Florida Department of Agriculture and Consumer Services for financial support. We also thank the farm crew and lab members of the weed science lab at GCREC, Balm. R.K.S. is a Post-doctoral Associate.

N.S.B. and L.Z. are Associate Professors.

S.A. is an Assistant Professor.

N.P. is a Professor of Plant Pathology.

N.S.B. is the corresponding author. E-mail: nsboyd@ufl.edu.

This is an open access article distributed under the CC BY-NC-ND license (https://creativecommons. org/licenses/by-nc-nd/4.0/). to increase the economic returns for growers compared with monocropping (Njoroge et al., 1993; Sandhu et al., 2020b, 2020a). However, there are some challenges associated with intercropping, such as the management of competition for nutrients, water, and light, which varies with many factors, such as plant population density, resource use efficiency, as well as temporal and spatial plant interactions (Gebru, 2015).

Plant population density is an important factor that can determine the success or failure of intercropping. It is defined as the number of plants per unit area and can affect the vegetative growth and yield of crops grown as a monocrop or an intercrop. The selection of the optimum plant density or spacing ensures optimal crop yield can be achieved (Fortin et al., 1994; Gebru, 2015). Competition can be among plants of the same species (intraspecific) or plants of two or more species (interspecific). A metaanalysis of multiple cropping studies found that intraspecific competition tends to be much stronger than interspecific competition. In some cases, interspecific competition can result in positive effects, whereas intraspecific competition tends to have negative consequences (Adler et al., 2018; Sandhu et al., 2020b). This could be because of "resource complementarity," which occurs when two intercropped plants are not competing for the same resource due to niche differentiation (Snaydon and Satorre, 1989). Intraspecific competition increases with population density because plants that share the same niche compete for resources such as water, nutrients, and light (Goldberg, 1990). Plant density needs to be optimized to establish effective intercropping systems.

Standard spacing for tomato and bell pepper production, when planted as sole crops, is well established (Freeman et al., 2019; Ozores-Hampton et al., 2015), but little information exists on the optimal plant spacing when intercropping. Given that intercrops have better resource use efficiency than sole crops, there is the potential that the overall plant density could be higher with an intercrop than with a monocrop (HauggaardNielsen et al., 2006).

A study on tomato and black nightshade competition reported that nightshade competed for light, nutrients, and reduced fruit yields by $\approx 36 \%$, but only when nightshade height surpassed the tomato height (Gonzalez Ponce et al., 1996). The same authors reported that nightshade competed with bell peppers at a much greater extent than tomatoes and reduced pepper yields by $93 \%$. These findings suggest that pepper is more susceptible to competition than tomato and that this difference might be associated with the height differential. There are no known published research papers that evaluate planting density for intercropped tomato and bell pepper. However, bell peppers have been successfully intercropped with different vegetables, including vegetables from the Bromeliad, Rose, Citrus, Legume, and Nightshade families, with improved insect management and higher yields (Kahn, 2010). 
We hypothesized that tomatoes or bell peppers planted as a sole crop would have higher yields compared with intercropped bell peppers and tomatoes, and that yields would decrease with increased planting density. The objectives of the study were a) to compare the growth and production of tomatoes and bell peppers at different plant densities both as an intercrop and a monocrop, and b) to determine the competitive effects of intercropping on the yields and morphology of tomatoes and bell peppers.

\section{Materials and Methods}

Experimental setup. Field experiments were conducted in the fall of 2018 and 2019 at the University of Florida's Gulf Coast Research and Education Center (lat. $27^{\circ} \mathrm{N}$, long. $82^{\circ} \mathrm{W}$ ) in Balm, FL. Soil pH was 5.5 to 6 , with $1.5 \%$ organic matter. The soil at the site was Myakka fine sand (sandy, siliceous, hyperthermic Oxyaquic Alorthod), with $92 \%$ sand, $4.8 \%$ silt, and $3.2 \%$ clay. Experiments were set up as a randomized complete block design with four replications, and all experiments were repeated in 2018 and 2019. Raised beds were shaped and fumigated on July 12 and 16 in 2018 and 2019, respectively, using a three-shanked fumigation rig, with backswept shanks set at a $20 \mathrm{~cm}$ depth with Pic-Clor 60 (37.1\% 1,3-Dichloropropene and $56.7 \%$ Chloropicrin) at $340 \mathrm{~kg} \cdot \mathrm{ha}^{-1}$. Two drip tapes (Jain Irrigation Inc., Haines City, FL) per row were installed, with emitters every $30 \mathrm{~cm}$ and a flow rate of $0.95 \mathrm{~L} / \mathrm{min} /$ $30 \mathrm{~m}$. Beds were then covered with virtually impermeable white plastic mulch (Berry Plastics Corp., Evansville, IN).

Six-week-old tomato transplants (Speedling Inc., Ruskin, FL) cv. Charger and two parallel rows of bell pepper cv. Aristotle were planted on the beds on 8 Aug. 2018 and 21 Aug. 2019. Both crops were planted on the same day, at varied spacing. There were eight planting density treatments (Table 1). The experiment was set up as completely randomized block design with four replications. The plot size was $9 \mathrm{~m}$ long and $0.7 \mathrm{~m}$ wide. The bell peppers were planted in two parallel rows (38 cm apart) on the sides of bed, and one row of tomato plants was transplanted in the center of bed (Fig. 1).

Irrigation, fertilization, disease, and pest management of tomato and bell pepper was done as per industry recommendations (Freeman et al., 2017). The fertilizer was applied at 226-112-112 (N-P-K) kg/ha to the tomato and pepper. Irrigation was scheduled for $1 \mathrm{~h}$ twice each day.
Data collection. The heights of five tomato and bell pepper plants per plot were recorded every $15 \mathrm{~d}$ for 2 months. Tomato and pepper height data were subjected to regression analysis, and the slope was calculated and used as an estimate of growth rate based on the change in height over time. Crop biomass was measured on 1-month-old [30 days after treatment (DAT)] and 2-month-old (60 DAT) tomato and bell pepper plants per plot by clipping two plants per plot at the soil surface and drying these in an oven at $60{ }^{\circ} \mathrm{C}$ until a uniform weight was obtained. Stem girth (diameter) at the base of the plant and internode length ( 3 internodes from the base) was measured on two bell pepper plants per plot at 1 and 2 months after the transplanting. The experiment row orientation was $\mathrm{N}-\mathrm{S}$, and row middles were $76.2 \mathrm{~cm}$ wide. Three photosynthetically active radiation measurements from top of plants at three times a day (morning, noon, and afternoon) and from three locations of bed (east, west, and top) were measured per plot with a Line Quantum Sensor LI-191R on 14 Oct. in 2018 and 2019 (LICOR Biosciences, Lincoln, NE). Fruit from six tomato and fourteen bell pepper plants was harvested twice at a 15-d interval upon maturity. Bell pepper weight and fruit number per plot were recorded. Tomato fruits were harvested and graded into four categories: small $(<58 \mathrm{~mm})$, medium (58$64 \mathrm{~mm})$, large $(64-73 \mathrm{~mm})$, and extra-large $(73-88 \mathrm{~mm})$, based on fruit diameter (Sargent, 1998).

Data analysis. Fruit weight, count, stem girth, and shoot biomass were analyzed by the PROC GLIMMIX procedure in SAS (version 9.4; SAS Institute, Cary, NC). Mean separations were done using Tukey's adjusted means comparisons. Plant height data were analyzed by regression using Sigma Plot (Systat Software Inc., San Jose, CA). The regression slope was compared among treatments using the Student's $t$ test.

Land equivalent ratio. Land equivalent ratio (LER) is the measure the productivity and effectiveness of intercropping (Amanullah et al., 2016). LER is defined as the "sum of the ratio of the yield/harvest of two crops under intercropping and yields of the sole crop at the same management level" (Seserman et al., 2018).

$$
\begin{aligned}
\text { LER }= & \frac{\text { Yield (tom) intercropped }}{\text { Yield (tom) monocropped }} \\
& +\frac{\text { Yield (pep) intercropped }}{\text { Yield (pep) monocropped }}
\end{aligned}
$$

\section{Results}

Pepper shoot biomass. Bell pepper shoot dry weight (DW) evaluated 1 month after transplant in 2018 was significantly greater than in 2019, with an average dry plant weight of 2.0 and $1.3 \mathrm{~g}$ per plant, respectively. However, planting density and the interaction between year and planting density treatments were not significant $(P=0.0693$ and $P=0.1539$, respectively), which indicates that the effect of planting density was consistent across years. After 2 months, the shoot DW of bell pepper shoots was significantly different between years $(P=0.0050)$ and planting density $(P<0.0001)$; but the interaction between year and planting density was not significant $(P=0.4982)$, and as a result, data were averaged across years due to the lack of significant interactions.

Plant density had no effect on bell pepper shoot DW when planted alone at both low and high planting density (Fig. 2). Bell pepper shoot DW at both densities when planted as a monocrop was significantly higher than bell peppers intercropped with tomatoes.

Pepper stem girth, shading, and internode length. The interaction between year and treatment was not significant $(P=0.9998)$ at 1 month (30 DAT) and 2 months (60 DAT) after planting. Pepper stem girth was unaffected by planting density after 1 month $(P=$ 0.533 ) of planting. However, 2 months after the planting, stem girth of monocropped bell pepper at both (Treatments 7 and 8) densities was higher than high-density bell pepper intercropped with tomato $(P=0.001)$ (Fig. 3). Internode length of 1- and 2month-old bell peppers was unaffected by planting density, but it followed the same trend as DW and stem girth. There was no light reduction observed among the different planting densities when measured on the top of bell pepper plants at the respective time of measurement. There was no difference in the growth rate of pepper or the pepper height at the end of the season between all $(P=0.458)$ planting densities.

Pepper yields. Pepper yield data did not differ between years $(P=0.0529)$ and were, therefore, pooled across years. Planting density significantly affected $(P<0.0001)$ bell pepper count and weight, with yields tending to decrease with increased plant density. Weight and count of monocropped bell peppers at $19-$ and $38-\mathrm{cm}$ in-row spacings were greater than the bell peppers intercropped with high-density tomatoes (Fig. 4A and B).

Tomato shoot biomass. Shoot dry weight (DW) of tomato plants at 1 month did not differ between years, but at 2 months, the DW was significantly higher in 2019 than 2018, with an average weight of 169 and $139 \mathrm{~g}$ per plant, respectively. Planting density affected the shoot DW of 1 -month-old $(P=0.0260)$ and 2 -month-old $(P<0.0001)$ tomato plants. Tomatoes planted at low density $(61 \mathrm{~cm} /$ standard spacing) with low-density bell peppers had the highest average shoot DW of $57.5 \mathrm{~g}$ per plant at 1 month. At 2 months (60 DAT), shoot DW of tomatoes planted alone 


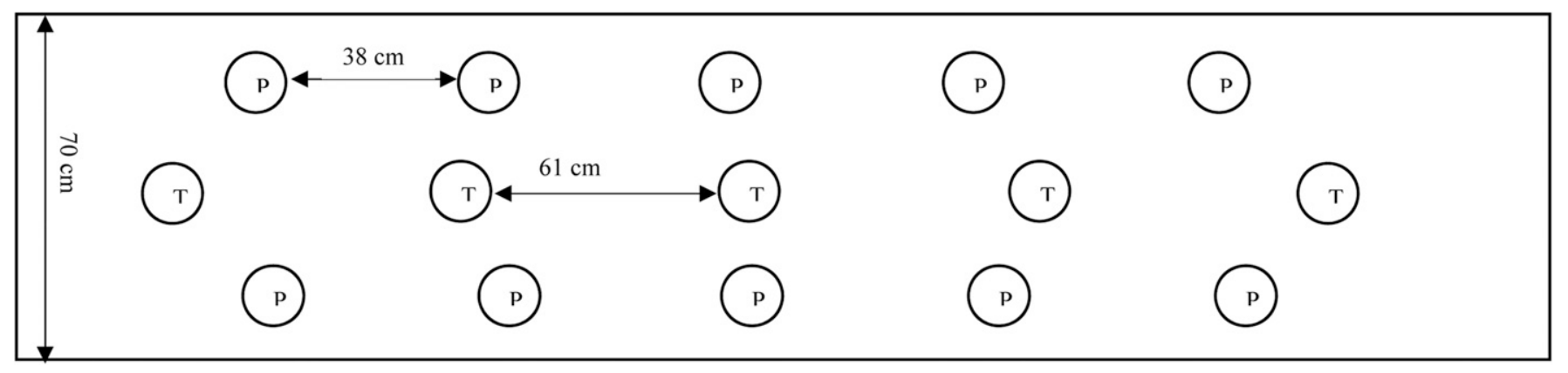

Fig. 1. Pictorial description of field planting pattern of intercropped tomato and bell pepper on a plastic-covered bed $(\mathrm{P}=$ bell pepper, $\mathrm{T}=$ tomato).

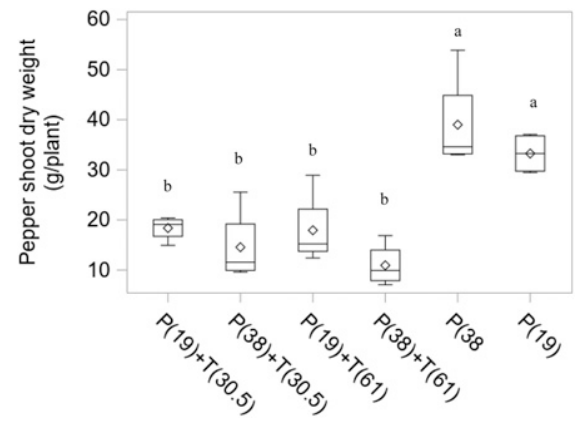

Fig. 2. Shoot dry weight of 2-month-old bell pepper plants averaged across four replications of six treatments (planting density) grown at GCREC, Balm in 2018 and 2019. Numbers in parentheses on the $x$-axis represent the plant-toplant spacing in $\mathrm{cm}$, where $\mathrm{P}=$ bell peppers and $\mathrm{T}=$ tomatoes. Different letters represent the LSmean (Least Squares Means) separation among different treatments at significance level of $P<0.05$.

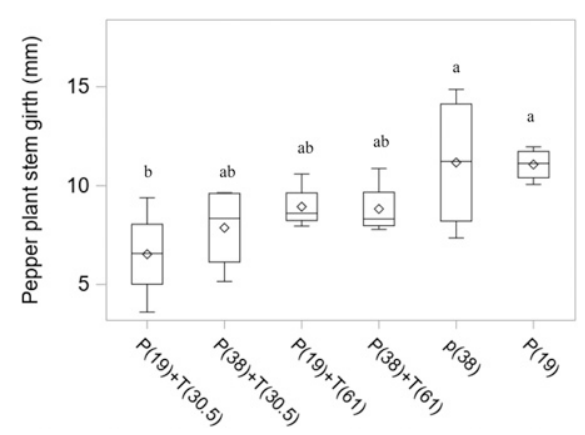

Fig. 3. Stem girth of 2-month-old bell pepper plants averaged across four replications of six treatments (planting density) grown at GCREC, Balm in 2018 and 2019. Numbers in parentheses on the $x$-axis represent the plant-to-plant spacing in $\mathrm{cm}$, where $\mathrm{P}=$ bell peppers and $\mathrm{T}=$ tomatoes. Different letters represent the LSmean separation among different treatments at a significance level of $P<0.05$.

at low density $(61 \mathrm{~cm})$ was significantly greater compared with that of tomatoes planted alone at high-density $(30.5 \mathrm{~cm})$ plantings (Fig. 5). However, the shoot DW of monocropped tomatoes planted at high density was not different from the intercropped high-density tomatoes. Similarly, there was no significant difference in the growth rate of tomatoes growing in different treatments, and the tomato height at the end of the season was the same in all treatments $(P=0.3961)$.

Tomato yields. Total marketable yield, including extra-large and large fruits, was significantly $(P<0.0001)$ greater in 2019 as compared with 2018. Moreover, the interaction between year and planting density of both the crops was significant $(P=0.0120)$, so data were presented separately for each year.

In 2018, extra-large fruit yields were significantly greater in low-density tomatoes intercropped with high-density bell peppers than monocrop tomatoes planted at high and low density $(P=0.0031)$. However, the extralarge fruit yields of high-density planted tomatoes intercropped with high-density planted bell peppers were not different from high-density tomatoes planted as a sole crop (Table 2). The total marketable $(P=0.3721)$ and large-grade tomato fruit $(P=0.0515)$ were unaffected by planting density.

In 2019, total and extra-large fruit tomato yields of low-density tomatoes intercropped with low-density bell peppers were significantly $(P=0.0028$ and $P=0.0025$, respectively) higher than high-density tomatoes intercropped with low-density bell peppers. The extra-large grade fruit yield of lowdensity tomatoes planted alone was significantly greater than the tomatoes planted alone at high density (Table 2).

Land equivalent ratio. At a low planting density [pepper $(38 \mathrm{~cm})+$ tomato $(61 \mathrm{~cm})$ ], the LER ratio was 1.72. At the high planting density [pepper $(19 \mathrm{~cm})+$ tomato $(30.5 \mathrm{~cm})]$, the LER ratio was 1.58. Furthermore, the LER of pepper $(19 \mathrm{~cm})+$ tomato $(61 \mathrm{~cm})$ and pepper $(38 \mathrm{~cm})+$ tomato $(30.5 \mathrm{~cm})$ were 1.33 and 1.1 , respectively. There was no significant difference between LER values of different treatments.

\section{Discussion}

Total tomato yield, marketable yield, and large-fruit yield were significantly different between years. However, despite the differences in results between years, the treatment effects remained consistent.

Differences in pepper growth were not apparent until 2 months after planting due to limited growth in the first month. Differences in pepper growth were also more prominent when bell peppers were planted with highdensity tomatoes. Peppers grown with tomatoes had less biomass, stem girth, and shorter internodes, but similar height than peppers growth alone. Given that we did not observe a measurable difference in shading between planting densities, differences in shoot growth was either affected by reduced nutrient availability or detecting the neighboring plants (Rajcan and Swanton, 2001). Plant nutrient demands can be met by increasing fertilizer inputs; however, addressing the effects on plant growth from nearby plants is challenging (Semchenko et al., 2007). Further studies are warranted to investigate the effects of nutrient management and interactions of neighboring plants in the intercropping of tomatoes and bell peppers.

In this study, shading was measured to quantify the effect on growth of two intercrops, tomato and bell pepper. Intercropping did reduce the light interception on bell peppers. However, this reduction was not significantly different among treatments (density) and did not cause any differences in plant height among various treatments. One possible explanation for lack of difference could be the wide spacing $(122 \mathrm{~cm})$ between plant rows, which allowed enough space for pepper plants to capture light from the row side. Another reason could be the same amount of shading on bell peppers planted with low- and high-density tomatoes. Because the high-density tomatoes intercropped with bell peppers were planted closely and the low-density tomatoes had better canopy growth, therefore both planting density resulted in a similar amount of shading on bell peppers. As far as the shading effect on bell peppers planted alone, closely planted bell pepper plants are likely to be shaded by each other. Therefore, pepper plant height (low and high density) did not vary among treatments, but biomass and stem girth were affected by the presence of tomatoes (high density).

The tomato canopy was much larger than the bell pepper canopy and was expected to affect the vegetative growth of bell peppers. Bell peppers grown in shade can have decreased stem diameter and reduced yield because of reduced chlorophyll in the leaves (Díaz-Pérez, 2013; Roberts and Anderson, 1994), which is in agreement with the results from this study. Furthermore, it has been 


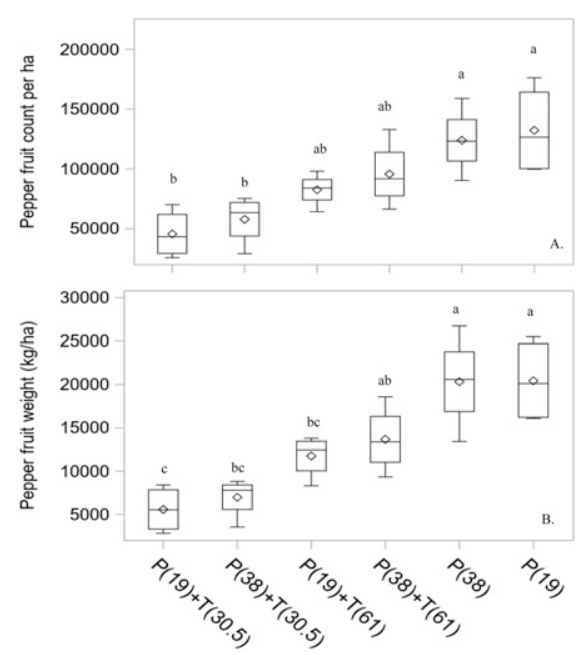

Fig. 4. Pepper fruit count (A) and weight \pm SE (B) averaged across four replications of six different treatments (planting density) grown at GCREC, Balm in 2018 and 2019. Numbers in parentheses on the $x$-axis represent the plant-toplant spacing in $\mathrm{cm}$, where $\mathrm{P}=$ bell peppers and $\mathrm{T}=$ tomatoes. Different letters represent the LSmean separation among different treatments at a significance level of $P<0.05$.

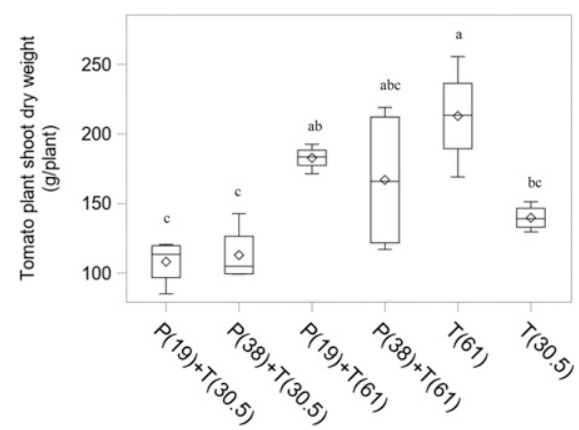

Fig. 5. Dry weight \pm SE of 3-month-old tomato plants averaged across four replications of six treatments (planting density) grown at GCREC, Balm in 2018 and 2019. Numbers in parentheses on the $x$-axis represent the plant-toplant spacing in $\mathrm{cm}$, where $\mathrm{P}=$ bell peppers and $\mathrm{T}=$ tomatoes. Different letters represent the LSmean separation among different treatments at a significance level of $P<0.05$.

Table 2. Total and extra-large tomato fruit yield averaged across four replications of six treatments (planting density) grown at GCREC, Balm in 2018 and 2019. Different letters represent the Lsmean separation across the column among different treatments at a significance level of $P<0.05$.

\begin{tabular}{|c|c|c|c|c|}
\hline \multirow[b]{2}{*}{ Plant spacing $(\mathrm{cm})$} & \multicolumn{2}{|c|}{2018} & \multicolumn{2}{|c|}{2019} \\
\hline & Total & $\overline{\text { Extra large }}$ & Total & Extra large \\
\hline & \multicolumn{4}{|c|}{$\mathrm{Mg} \mathrm{T} / \mathrm{ha}$} \\
\hline$P(38)+T(61)$ & 18.1 & $17.2 \mathrm{ab}$ & $50.9 \mathrm{a}$ & $39.8 \mathrm{a}$ \\
\hline$P(38)+T(30.5)$ & 14.3 & $13.2 \mathrm{abc}$ & $24.8 \mathrm{c}$ & $18.7 \mathrm{~b}$ \\
\hline$P(19)+T(61)$ & 23.1 & $18.8 \mathrm{a}$ & $41.7 \mathrm{abc}$ & $34.1 \mathrm{ab}$ \\
\hline$P(19)+T(30.5)$ & 16.3 & $7.3 \mathrm{bc}$ & $33.3 \mathrm{bc}$ & $25.6 \mathrm{ab}$ \\
\hline $\mathrm{T}(61)$ & 17.1 & $8.0 \mathrm{bc}$ & $46.6 \mathrm{ab}$ & $38.1 \mathrm{a}$ \\
\hline $\mathrm{T}(30.5)$ & 16.5 & $6.2 \mathrm{c}$ & $26.9 \mathrm{bc}$ & $19.6 \mathrm{~b}$ \\
\hline$P$ value & 0.0515 & 0.0031 & 0.0028 & 0.0025 \\
\hline
\end{tabular}

Different lowercase letters are showing significant difference at $P<0.05$ using Tukey adjusted means within the columns comparing different transplanting dates.

$\mathrm{P}=$ bell peppers; $\mathrm{T}=$ tomatoes

proved that an increase in chlorophyll could increase the photosynthetic activity of plants (Zhang et al., 2017). In addition, the belowground competition for nutrients among intercropped plants could also attribute to reduced bell pepper biomass and yields. Nitrogen is the major constituent of chlorophyll and all other proteins/amino acids involved in major plant metabolism processes (AbuZahra, 2012); its content in plants depends on nutrient availability. Therefore, the competition for nitrogen increases among crops planted at high densities and affects the vegetative growth of plants (Palta, 1990). Thus the recommended rate of fertilizer was applied to these crops.

The lower biomass indicates less leaf area and lowered accumulation of resources needed to produce an ample amount of fruit. The source-sink relationships between plants shows that sinks (fruit) cannot produce high yields when the source (roots/leaves) capacity is limited (Venkateswarlu and Visperas, 1987). It has been further reported that fully grown leaves become the source (at later plant growth stages) to produce seed-bearing fruits; however, a smaller number of leaves and less leaf area is a poor source to produce a high (or enough) number of sinks. Interspecific competition was more critical than the intraspecific competition for bell pepper. Tomato competition reduced bell pepper yields, but low-density tomato yields were unaffected by the presence of low- and highdensity bell peppers. This could be due to higher resource-use efficiency of tomatoes compared with bell peppers. In contrast, bell peppers planted with low- and high-density tomatoes had lower yields and biomass.

Higher DW in tomatoes planted at low planting density $(61 \mathrm{~cm})$ with or without bell peppers, compared with high-density tomatoes, further supports our theory that intraspecific competition is more important in tomatoes than interspecific competition. The physiological aspect of competition is reflected in the yields of bell peppers. Higher plant mortality due to fusarium wilt in 2018 vs. 2019 may explain the yield differences. However, yields followed similar trends in both years. Yields were higher in the case of tomatoes grown at $61 \mathrm{~cm}$ vs. $30.5 \mathrm{~cm}$, with and without bell peppers. There was a reduc-

HortScience Vol. 56(2) February 2021 tion in 2019 total tomato yield of $18 \%$ when tomatoes and bell peppers were intercropped at low density, compared with intercropping with high-density bell peppers. Furthermore, there was a $42 \%$ reduction in yield when tomatoes were planted alone at high density, compared with the ones planted in sole cropping at low density. The higher yield reduction signifies that intraspecific competition is of more significance than interspecific competition. The results agree with the study reporting low-density tomatoes producing significantly higher yields, compared with high-density tomatoes (Ara et al., 2007). In contrast, another study reported no difference in tomato yields when planted at a $35-\mathrm{cm}$ and $50-\mathrm{cm}$ plant-to-plant spacing. This could be due to better resource-use efficiency. Moreover, the yields were reduced at low density (70-cm plant-to-plant spacing) (Yohannes and Tadesse, 1998).

LER greater than 1 indicated that there was greater land use efficiency when intercropping bell pepper and tomatoes compared with monocropping. Similarly, LER ratios of above 1 were reported in different studies on maize intercropping with okra and tomatoes (Ijoyah and Jimba, 2012; Sharma and Tiwari, 1996). The tomatoes and bell peppers intercropped at low densities resulted in the highest LER compared with mono- and other intercropped treatments. The comparison of intercropped vs. monocropped treatment shows that tomatoes planted alone had lower resource-use efficiency compared with tomatoes planted with bell peppers where the maximum yield was attained at low planting density. However, these results could differ from the planting density of both crops. Baumann et al. (2001) indicated that it is not possible to state the true yield advantage based on planting density; and that by increasing the density in monocropping, higher yields can be achieved. However, results from the current study indicate that by increasing the planting density in monocrop, the yields were reduced compared with tomatoes planted at low density. So, based on the LER of this cropping system, it is better to increase planting density via an intercrop than to increase planting density of a mono crop. There are limited studies on intercropping of tomatoes and bell peppers, and further research is needed to determine if this is an economically viable system.

In summary, intercropping vegetable crops has the potential to increase crop yields and may increase farm income. We conclude that intercropping tomato and bell pepper has higher land-use efficiency than either crop alone, or could potentially increase overall profits even though the yields of each specific crop are lower. However, the profits are mainly determined by the market price of each crop. Given that tomato yields were equal when planted with both low- and highdensity bell peppers, we suggest that tomatoes are less sensitive to interspecific competition. Intercropping is likely to be most successful when both crops are planted at 
the lowest recommended planting density for the monocrop.

\section{Literature Cited}

Abu-Zahra, T.R. 2012. Vegetative, flowering and yield of sweet pepper as influenced by agricultural practices. Middle East J. Sci. Res. 11:1220-1225.

Adler, P.B., D. Smull, K.H. Beard, R.T. Choi, T. Furniss, A. Kulmatiski, J.M. Meiners, A.T. Tredennick, and K.E. Veblen. 2018. Competition and coexistence in plant communities: Intraspecific competition is stronger than interspecific competition. Ecol. Lett. 21:1319-1329.

Amanullah. F. Khan, H. Muhammad, A. Ullah Jan, and G. Ali. 2016. Land equivalent ratio, growth, yield and yield components response of mono-cropped vs. inter-cropped common bean and maize with and without compost application. Agr. Biol. J. N. Amer. 7:40-49.

Ara, N., M.K. Bashar, S. Begum, and S.S. Kakon. 2007. Effect of spacing and stem pruning on the growth and yield of tomato. Intl. J. Sustain. Crop Prod. 2:35-39.

Baumann, D.T., L. Bastiaans, and M.J. Kropff. 2001. Competition and crop performance in a leek-celery intercropping system. Crop Sci. 41:764-774.

Biswas, T., Z. Guan, and F. Wu. 2017. An overview of the US bell pepper industry. Vegetable production handbook of Florida. IFAS Extension, Univ. Florida, Gainesville, FL.

Boudreau, M.A. 2013. Diseases in intercropping systems. Annu. Rev. Phytopathol. 51:499-519.

Díaz-Pérez, J.C. 2013. Bell pepper (Capsicum annum L.) crop as affected by shade level: Microenvironment, plant growth, leaf gas exchange, and leaf mineral nutrient concentration. HortScience 48:175-182.

Fortin, M.C., J. Culley, and M. Edwards. 1994. Soil water, plant growth, and yield of stripintercropped corn. J. Prod. Agr. 7:63-69.

Freeman, J.H., E.J. McAvoy, N.S. Boyd, R. Kanissery, H.A. Smith, J. Desaeger, J.W. Noling, and G.E. Vallad. 2019. Chapter 18. Tomato production. Vegetable production handbook of Florida. IFAS Extension, Univ. Florida, Gainesville, FL.

Freeman, J.H., E.J. McAvoy, N.S. Boyd, R. Kanissery, M. Ozores-Hampton, H.A. Smith, J. Desaeger, J.W. Noling, and G.E. Vallad. 2017. Chapter 18. Tomato production. Vegetable production handbook of Florida, HS739.
IFAS Extension, Univ. Florida, Gainesville, FL.

Gebru, H. 2015. A review on the comparative advantage of intercropping systems. J. Biol. Agric. Healthc. 5:28-38.

Goldberg, D.E. 1990. Components of resource competition in plant communities, p. 27-49. In: James B. Grace and David Tilman (eds.). Perspectives on plant competition. Academic Press, San Diego, CA.

Gonzalez Ponce, R., C. Zancada, M. Verdugo, and L. Salas. 1996. Plant height as a factor in competition between black nightshade and two horticultural crops (tomato and pepper). J. Hort. Sci. 71:453-460.

Guan, Z., T. Biswas, and F. Wu. 2017. The U.S. tomato industry: An overview of production and trade. Universiity of Florida 1-4.

Hauggaard-Nielsen, H., M.K. Andersen, B. Jørnsgaard, and E.S. Jensen. 2006. Density and relative frequency effects on competitive interactions and resource use in pea-barley intercrops. F. Crop. Res. 95:256-267.

Ijoyah, M.O. and J. Jimba. 2012. Evaluation of yield and yield components of Maize (Zea mays L.) and okra (Abelmoschus esculentus L. Moench) intercropping system at Makurdi, Nigeria. J. Biodivers. Environ. Sci. 2:38-44.

Kahn, B.A. 2010. Intercropping for field production of peppers. HortTechnology 20:530-532.

Njoroge, J.M., K. Waithaka, and J.A. Chweya. 1993. Effects of intercropping young plants of the compact Arabica coffee hybrid cultivar Ruiru 11 with potatoes, tomatoes, beans and maize on coffee yields and economic returns in Kenya. Exp. Agr. 29:373-377.

Ozores-Hampton, M., N.S. Boyd, E.J. McAvoy, H.A. Smith, G.E. Vallad, and S. Bell. 2015. Pepper production, p. 145-159. Vegetable production handbook of Florida. IFAS Extension, Gainesville, FL.

Palta, J.P. 1990. Leaf chlorophyll content. Remote Sens. Rev. 5:207-213.

Rajcan, I. and C.J. Swanton. 2001. Understanding maize-weed competition: Resource competition, light quality and the whole plant. F. Crop. Res. 71:139-150.

Rao, M.R. and R.W. Willey. 1980. Evaluation of yield stability in intercropping: Studies on sorghum/pigeonpea. Exp. Agr. 16:105-116.

Raseduzzaman, M. and E.S. Jensen. 2017. Does intercropping enhance yield stability in arable crop production? A meta-analysis. Eur. J. Agron. 91:25-33.
Roberts, B.W. and J.A. Anderson. 1994. Canopy shade and soil mulch affect yield and solar injury of bell pepper. HortScience 29:258-260.

Sandhu, R.K., N.S. Boyd, Q. Qiu, and Z. Guan. 2020a. Optimization of planting dates of Jalapeno pepper (Capsicum annuum "Jalapeño" L.) and cantaloupe (Cucumis melo var. cantalupensis Ser.) relay cropped with strawberry (Fragaria $\times$ ananassa Duchesne). PLoS One 15:e 0236677.

Sandhu, R.K., N.S. Boyd, S. Sharpe, Z. Guan, Q. Qiu, T. Luo, and S. Agehara. 2020b. Management of relay-cropped strawberry and eggplant to maximize yield and economic return. HortScience 55:1-7.

Sargent, S.A. 1998. Tomato production guide for Florida: Harvest and handling 1. Coop. Ext. Serv., Inst. Food Agr. Sci., Univ. Florida. 1-5.

Semchenko, M., M.J. Hutchings, and E.A. John. 2007. Challenging the tragedy of the commons in root competition: Confounding effects of neighbour presence and substrate volume. J. Ecol. 95:252-260.

Seserman, D.M., M. Veste, D. Freese, A. Swieter, and M. Langhof. 2018. Benefits of agroforestry systems for land equivalent ratio-Case studies in Brandenburg and Lower Saxony, Germany. Agrofor. as Sustain. Land Use, Nijmegen, Netherlands 3:26-29.

Sharma, N.K. and R.S. Tiwari. 1996. Effect of shade on yield and yield contributing characters of tomato cv. Pusa Ruby. Recent Hort 3:89-92.

Snaydon, R.W. and E.H. Satorre. 1989. Bivariate diagrams for plant competition data: Modifications and interpretation. J. Appl. Ecol. 26:1043-1057.

USDA-NASS. 2016. Statistics of vegetables and melons. Agr. Stat. 2016:1-41.

Venkateswarlu, B. and R.M. Visperas. 1987. Source-sink relationships in crop plants. Intl. Rice Res. Institute, Manila, Philippines. 3-19.

Yohannes, F. and T. Tadesse. 1998. Effect of drip and furrow irrigation and plant spacing on yield of tomato at Dire Dawa, Ethiopia. Agr. Water Mgt. 35:201-207.

Zhang, J., Y. Wang, P. Wang, Q. Zhang, C. Yan, F. Yu, J. Yi, and L. Fang. 2017. Effect of different levels of nitrogen, phosphorus, and potassium on root activity and chlorophyll content in leaves of Brassica oleracea seedlings grown in vegetable nursery substrate. Hort. Environ. Biotechnol. 58:5-11. 